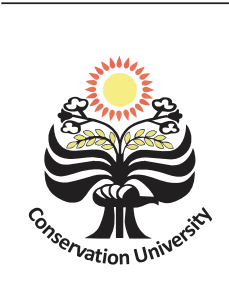

Biosaintifika 8 (1) (2016) 96-104

\title{
Biosaintifika
}

Journal of Biology \& Biology Education

http://journal.unnes.ac.id/nju/index.php/biosaintifika

\section{Exploration of Potential Actinomycetes from CIFOR Forest Origin as Antimicrobial, Antifungus, and Producing Extracellular Xylanase}

\author{
Sipriyadi ${ }^{1}$, Yulin Lestari ${ }^{2}$, Aris Tri Wahyudi ${ }^{2},{ }^{\bowtie}$ Anja Meryandini ${ }^{2}$, Maggy Thenawidjaja \\ Suhartono $^{3}$
}

DOI: 10.15294/biosaintifika.v8i1.5052

${ }^{1}$ Graduate School of Bogor Agricultural University, Microbiology Study Program, Department of Biology, Faculty of Mathematics and Natural Sciences, Bogor, Indonesia

${ }^{2}$ Department of Biology, Faculty of Mathematics and Natural Sciences, Bogor Agricultural University, Indonesia

${ }^{3}$ Department of Food Science and Technology, Faculty of Agricultural Technology, Bogor Agricultural University, Indonesia

\section{History Article}

Received 12 February 2016

Approved 9 March 2016

\section{Keywords:}

actinomycetes; antimicrobial, antifungus; xylanase extracellular
Published 29 March 2016

\begin{abstract}
This study aimed to isolate and explore the actinomycetes of CIFOR forest origin as an antimicrobial and antifungal agent, to produce an extracellular xylanase, and to identify isolates based on $16 \mathrm{~S}$ rRNA gene sequences. Actinomycetes were isolated using Humic-acid Vitamin-B agar (HV) media. Actinomycetes colonies that grow on the medium $\mathrm{HV}$ was subsequently purified by growing them on yeast malt agar (YMA) media), then an antagonistic test of selected bacteria against Bacillus sp., Escherichia coli, Fusarium oxysporum, and Sclerotium sp was performed. Xylanase activity test was detected by observing a clear zone, followed by identification. Total of 35 isolates of actinomycetes isolated based on their colony morphology characteristics and diverse types of spore chains showed Streptomyces spp. of isolates CFR-06, CFR-15, CFR-17, CFR-18, and CFR-19 were able to inhibit the growth of Bacillus sp.. The highest inhibition zone has a diameter of $10.1 \mathrm{~mm}$ (isolate CFR17). Isolates CFR-01 and CFR- 15 were able to inhibit the growth of E. coli with the highest inhibition zone diameter of $5.1 \mathrm{~mm}$ (isolate CFR-15). Isolates CFR-29 and CFR-12 were able to inhibit the growth of F. oxysporum while isolate CFR-35 were able to inhibit the growth of Sclerotium sp.. Xylanase activity test showed that isolates CFR-12, CFR-20, CFR-22, CFR-24, CFR-25, CFR-30, CFR-33, CFR-34 have an ability to produce extracellular xylanase enzyme. Actinomycetes isolate (Xyl_22) as a potential xylanase enzyme producer was closely related with Streptomyces drozdowicii by the maximum similarity of $99 \%$.
\end{abstract}

\section{How to Cite}

Sipriyadi, S., Lestari, Y., Wahyudi, A., Meryandini, A., \& Suhartono, M. T. (2016). Exploration Potential CIFOR Forest actinomycetes origin as Antimicrobial, Anti Fungus and Producing Enzymes Extracellular Xylanase. Biosaintifika: Journal of Biology \& Biology Education, 8(1), 96-104.

C 2016 Semarang State University

\footnotetext{
$\triangle$ Correspondence Author:
}

Darmaga, Bogor, Jawa Barat, Indonesia 16680

p-ISSN 2085-191X

E-mail: ameryandini@yahoo.co.id 
Sipriyadi, et al. / Biosaintifika 8 (1) (2016) 96-104

\section{INTRODUCTION}

Indonesia is a country with abundant natural resources. Forest Center for International Forestry Research (CIFOR), which is located in Situ Gede, Sindang Barang, West Bogor, is one of the forests with the high richness of flora, fauna, and microbial germplasm. This forest is still wellmaintained because it is protected by the firm laws and regulations. Nutrient availability found in the soil of forest area is a factor that determines the diversity of microbes in this habitat. One of the microbes which are dominantly found in nature is actinomycetes. The existence of actinomycetes in the environment is very abundant, especially in the rhizosphere because this layer provides many nutrients needed by these microbes.

Hemicellulose is a plant cell wall component apart cellulose and lignin in with its composition reaches $25-30 \%$ of the total dry weight of the wood (Perez et al., 2002). The largest component of hemicellulose in the plant cell is xylan. Xylan is the second most abundant polysaccharide in nature after cellulose (Saha, 2003; Subramaniyan and Prema, 2002). Xylan is the complex heteropolysaccharide with a backbone or basic chain composed of homopolymer units D-xylopyranose that linked by $ß-1,4-D$-xylose (Saha, 2003; Tseng et al., 2002). Its backbone or basic chain may also contain some substituents which later became the side chains such as Oacetyl, $\alpha$-L-arabinofuranosyl, D-glucuronyl, and the residue Omethyl-D-glucuronyl (Silveira et al., 1999). Thus to effectively hydrolyze xylan into its constituent monomers, a system of enzymes that can work as synergy and have a special function was needed (Ryan et al., 2003).

Xylan hydrolysis involves two main types of enzymes i.e. endo-1,4-ß-xylanase (1,4-ß-xylan xylanohydrolase) and $\beta$-xylosidase (ß-D-xylosida xylohydrolase) (Sunna and Antranikianl, 1997; Ali et al., 2004). Endo-1,4-ß-xylanase polymerizes xylan through the hydrolysis of $\beta-1.4$ to xylooligosaccharide and xylose randomly, and $ß$-xylosidase hydrolyzes xylooligosaccharide from the non-reducing end into free xylose (Gilbert and Hazlewood, 1993). Meanwhile, the side groups that exist on the xylan are released by $\alpha$-Larabinofuranosidase, $\alpha$-D-glucuronidase, acetyl xylan esterase and galactosidase (Subramaniyan and Prema, 2002).

Some groups of microbes have been found to produce xylanase enzyme, including fungi (Lin et al., 1999; Saha, 2003), bacteria (Sunna et al., 1997; Beg et al., 2001), and protozoa (Devillard et al., 2003). One group of potential xylanase- producing bacteria is the actinomycetes, especially Streptomyces group (Ruiz-Arribas et al., 1995; Georis et al., 2000; Kaneko et al., 2000; Wang et al., 2007; Kansoh and Nagieb, 2004).

Actinomycetes is a Gram-positive of filamentous bacteria that can form mycelia and spores (Madigan et al, 2000). Actinomycetes can live in the soil aerobic zone, as saprophyte with a wide range of organic substrates, in freshwater and marine sediments. Some species of actinomycetes groups have an important role in decomposition of some types of polymers. The ability to degrade macromolecules is supported by the production of various extracellular enzymes. Some types of Streptomyces are known to produce xylanase enzyme that degrades complex lignocellulose.

Instead of producing extracellular xylanase enzyme, actinomycetes group especially Streptomyces was reported to have antimicrobial activity. Research conducted by Oskay et al., (2004) has been succeeded to isolate 50 isolates of actinomycetes from agricultural soil. Seventeen of the 50 isolates were able to inhibit the growth of bacteria Erwinia amylovora, Pseudomonas viridiflova, Agrobacterium tumefaciens, Clavibacter michiganensissubs, Bacillus subtilis ATTC 6633, Klebsiella pneumoniae ATTC10031, Enterococcus feacalis ATCC 10541, Staphylococcus aureus ATCC 6538, Escherichia coli ATCC 29 998, Sarcina lutea ATCC 9341. Ambarwati \& Trisnawati (2009) reported actinomycetes from rice field soil in Klaten that has antibacterial activity against Staphylococcus aureus ATCC 25923. The other potency of actinomycetes is as antifungal. Many of actinomycetes bacteria have the ability to produce antifungal. Streptomyces, for example, can produce the antifungal amphotericin B isolated from Streptomyces nodosus, Kandisidin from Streptomyces griseus, and nystatin from Streptomyces noursei (Aghighi et al., 2004).

Based on the background above, it is necessary to explore actinomycetes origin from the soil of Center for International Forestry Research (CIFOR) Situ Gede, Sindang Barang, West Bogor, which has potential roles as antimicrobial, antifungal, and producer of extracellular xylanase. It also needs to perform identification of selected isolates based on 16S rRNA gene sequences.

\section{METHODS}

\section{Isolation and cultivation of soil microbe}

Soil samples were used for actinomycetes resources taken from Center for International Forestry Research (CIFOR) Situ Gede, Sindang 
Barang, West Bogor, Indonesia. Soil taken from the field was dried for one night at room temperature and incubated at $60^{\circ} \mathrm{C}$ for 2 hours. Furthermore, $1 \mathrm{~g}$ of a soil sample was dissolved in $9 \mathrm{~mL}$ of saline $(0.85 \% \mathrm{NaCl})$, and serial dilution up to $10^{-5}$ was performed. A total of $100 \mathrm{~mL}$ solutions at $10^{-4}$ and $10^{-5}$ dilution was spread in a petri dish containing agar medium that made by humic acid vitamin B (media HV) with cycloheximide (50 mg / L media), and nalidixic acid (20 mg / $\mathrm{L}$ media). Furthermore, it was incubated at room temperature $\left(28^{\circ} \mathrm{C}\right)$ for $1-2$ weeks until actinomycetes colony growth can be observed well.

\section{Purification and microscopic observation of actinomycetes}

Isolated soil microbes that have grown well on media HV were purified on agar Yeast Malt Extract (YMA). Purification of soil actinomycetes was done by two repetitions. The next step was the incubation of isolates for seven days at a room temperature. After that, observation of morphological of spore chain diversity was performed. Actinomycetes isolates were placed on the objective glass with a drops of water on it, then observed at 100x and 400x magnification.

\section{Antagonistic test of actinomycetes against $\mathrm{Ba}$ -} cillus sp., E. coli, Sclerotium sp. and F. oxysporum

The direct antagonistic test was performed using the dual culture method. The first step was pouring the semisolid media with four $\mathrm{mL}$ E. coli and Bacillus sp. by the optimum concentration of $10^{8}$ cells / $\mathrm{mL}$ on the top of nutrient media that has been solidified. Actinomycetes colonies which have grown on YMA medium for seven days were taken by the sterile suction with a diameter of $8 \mathrm{~mm}$ and placed on the semisolid NA medium that has been solidified, the colony was in the upside down position. Furthermore, cultures were incubated for 24 hours at a temperature of $37^{\circ} \mathrm{C}$. A clear zone formed was observed and the inhibition value against the target bacteria was measured. The same method was carried out to test the antagonistic ability against Bacillus sp. The level of inhibition was determined from the difference between the clear zone $\left({ }^{\gamma} \mathrm{O}\right)$ and the diameter of the tested isolates $\left({ }^{\gamma}\right)$ or by equation $\Delta^{\gamma}={ }^{\gamma} \mathrm{O}_{-}^{\gamma}$, where +++ if $\Delta^{\gamma}>=20 \mathrm{~mm}$, ++ if $\Delta^{\gamma}>=10-19 \mathrm{~mm}$, + if $\Delta^{\gamma}>=5-9$, and no inhibitory activity (-)if $\Delta^{\gamma}>=5 \mathrm{~mm}$ (El-Tarabily et al., 2000). The streaked of actinomycetes did antibiotic test against Sclerotium sp. and F. oxysporum isolates onto four separate areas on the YMA media which has been added to nalidixic acid (1 $\mathrm{mg} /$ 1) and incubated for four days at room temperature. Sclerotium sp. and F. Exosporium colonies were taken by sterile suction with a diameter of $5 \mathrm{~mm}$, placed in the middle of the petri dish, and incubated at room temperature four days (Sclerotium sp.) and 5-7 days (F. oxysporum).

\section{Screening and identification of actinomycetes producing extracellular xylanase enzyme}

Screening of isolates producing extracellular xylanase enzyme was done by growing the actinomycetes isolates on oat spelled xylan media and incubated for four days at room temperature. After three days, colonies of bacteria that grow were recultured on plates containing xylan medium and $0.1 \%$ congo red for observing the clear zone easier. Furthermore it rinsed with $\mathrm{NaCl} 5$ $\mathrm{M}$. The determination of the potential xylanaseproducing isolates was done by selecting colonies that formed the clear zone with the widest diameter. Colonies that have a clear zone were purified by the quadrant method and rejuvenated by streaking it on YMA agar. Selected actinomycetes isolates were further identified using $16 \mathrm{~S}$ rRNA gene. Isolates were grown on yeast malt broth media for 48 hours and then total genomic of bacteria were isolated by special bacterial isolation kit (Genaid) following manufacturer's instruction. Furthermore, The Genomic DNA was amplified by using specific prokaryotic primers (Marchesi et al., 1998) i.e. forward primer 63f (5'-CAG GCCCACTAAGTCATGCAA-3 ') and reverse primer 1387r (5'-GGGCGGGTAWGTCAAGGC-3'). The PCR reaction containing 0.5 $\mathrm{mL}$ of DNA polymerase enzyme LaTaq (long amplification Taq polymerase), $25 \mathrm{~mL}$ of $2 \mathrm{x}$ GC buffer, $8 \mathrm{~mL}$ of dNTP mixture, $1.5 \mathrm{~mL}$ of each primer (10 pmol), $9.5 \mathrm{~mL}$ of $\mathrm{ddH}_{2} \mathrm{O}$, and $4 \mathrm{~mL}$ of DNA template. PCR condition used was predenaturation ( $94^{\circ} \mathrm{C}, 4$ minutes), denaturation (94 ${ }^{\circ} \mathrm{C}, 45$ seconds), annealing $\left(55^{\circ} \mathrm{C}, 1 \mathrm{~min}\right)$, elongation $\left(72^{\circ} \mathrm{C}, 1 \mathrm{~min} 10 \mathrm{sec}\right)$, and post-PCR $\left(72^{\circ} \mathrm{C}, 7\right.$ minutes) for 30 cycles. The raw sequencing data was trimmed and assembled using ChromasPro program version 1.5. Assembling data was further analyzed using Blast from NCBI/ national center for biotechnology information. Furthermore, data was aligned using MEGA 5.0 (Tamura et al., 2011). Construction of phylogenetic tree was performed to show the affiliation of actinomycetes isolate Xyl_22 and other nonactinomycetes using Neighbor Joining method with bootstrap 1000x replications (Felsenstein, 1985). 


\section{RESULTS AND DISCUSSION}

Total of 35 actinomycetes isolates origin from the soil can grow well on YMA media with the variation of colony morphology presented in Figure 1. Actinomycetes colonies mostly have a rough morphology which grown on the agar, in contrast to other microbial colonies that appear in the soft morphology on the agar media.

The diversity of 15 colonies of actinomycetes showed in Figure 1 were able to form aerial and substrate mycelia varied from white, beige, brown, gray. All of these isolates belonged to genus Streptomyces sp. Overall, those isolates have a widely fungi-like branching mycelia, and the spores have variation including curly, hook, and spiral (Figure 1). According to Ghadin et al., (2008), the growth of Streptomyces sp. on the solid media showed aerial mycelia with white, brown, and gray spores. The spore of Streptomyces sp. has spirales (S), recti flexibles (RF), and retinaculiaperti (RA) types of chain arrangement (Shirling and Gottlieb, 1996). Based on the type of spore chain arrangement, all isolates showed Streptomyces spp. characteristics of RF and RA spore types.

The result of the direct antagonistic test on actinomycetes isolates to the growth of Bacillus sp. showed the formation of a clear zone indicating the inhibitory activity of actinomycetes isolates in the age of 7 days against Bacillus sp. (Figure 2). Total of 35 isolates tested against Bacillus sp., only five isolates showed significant inhibition based on criteria proposed by (El-Tarabily et al., 2000).
From the five isolates, inhibitory activity with the largest clear zone was produced by isolates 17 with the clear zone of $10.1 \mathrm{~mm}(++)$ (Table 1).

The results were almost similar to direct antagonistic test of actinomycetes isolates on the growth of E.coli. Figure 2 showed the formation of a clear zone indicating the inhibitory activity of actinomycetes isolates with age of 7 days against E.coli. Total of 35 isolates were tested against E. coli. However, only two of them showed a significant inhibitory activity based on the criteria stated by El-Tarabily et al., (2000). Those isolates produced inhibition zone of $5.0 \mathrm{~mm} \mathrm{(+)}$ to isolate CFR-01 and $5.1 \mathrm{~mm}(+)$ to isolate CFR15 (Table 1).

From 35 isolates tested against $F$. oxsporum and Sclerotium sp., three isolates have the ability to inhibit those fungi. Both isolates CFR-29, and 12 CFR have an inhibitory activity on the growth of F. oxysporum while CFR-35 specifically inhibited Sclerotium sp. The highest inhibition zone with a diameter greater than or equal to 5 $\mathrm{mm}(+)$ was showed by isolate CFR-29 (Figure 2). This was proved by the ability of that isolate to inhibit the growth of $F$. oxysporum up today 21 (3 weeks) after the antagonistic test. Cao et al., (2005) reported Streptomyces was able to inhibit the endophytic F. oxysporum. Taechowisan et al., (2005) was also reported that Streptomyces aureofaciens CMUAc130 was able to inhibit $F$. oxysporum. Research conducted by Rochmawati et al., (2015) reported that the growth of the Escherichia coli was able to be inhibited by the active com-
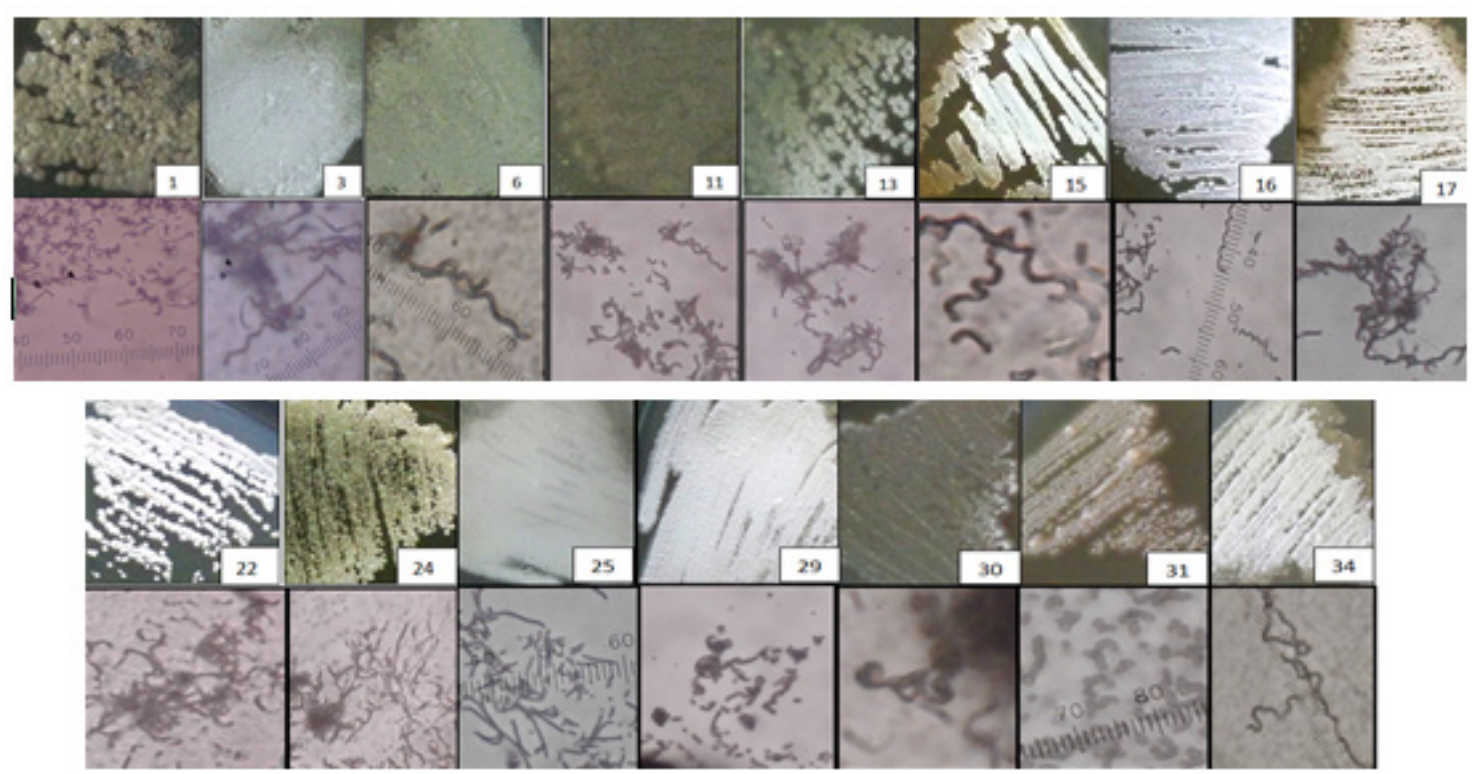

Figure 1.Variation of colony morphology of Streptomyces sp. from CIFOR forest origin after seven days of incubation at YMA media (upper figure).The type of spore chains Streptomyces sp. was observed by a light microscope using 400x magnification (lower figure). 
Table 1. Diameter and notation of inhibition zone on direct antagonist test of actinomycetes isolate to the growth of Bacillus sp. and E. coli.

\begin{tabular}{lcccc}
\hline Antagonistic bacteria & $\begin{array}{c}\text { Number of } \\
\text { isolate }\end{array}$ & $\begin{array}{c}\text { Diameter of isolate } \\
(\gamma)(\mathrm{mm})\end{array}$ & $\begin{array}{c}\text { Diameter of clear } \\
\text { zone }\left({ }^{\gamma} \mathrm{O}\right)(\mathrm{mm})\end{array}$ & $\Delta^{\gamma}={ }^{\gamma}{ }_{\mathrm{O}-}^{\gamma}$ \\
\hline \multirow{3}{*}{ Bacillus sp. } & CFR-06 & 9.0 & 14.0 & $5.0(+)$ \\
& CFR-15 & 9.0 & 17.7 & $8.7(+)$ \\
& CFR-17 & 9.5 & 18.6 & $10.1(++)$ \\
Escherichia coli & CFR-18 & 9.0 & 14.0 & $5.0(+)$ \\
& CFR-19 & 9.0 & 16.1 & $7.1(+)$ \\
& CFR-1 & 8.5 & 13.5 & $5.0(+)$ \\
\hline
\end{tabular}

Description: +++ if $\Delta^{\gamma}>=20 \mathrm{~mm}$. ++ If $\Delta^{\gamma}>=10-19 \mathrm{~mm}$. + If $\Delta^{\gamma}>=5-9$. and no inhibitory activity (-)if $\Delta^{\gamma}<=5 \mathrm{~mm}$ (El-Tarabily et al., 2000).

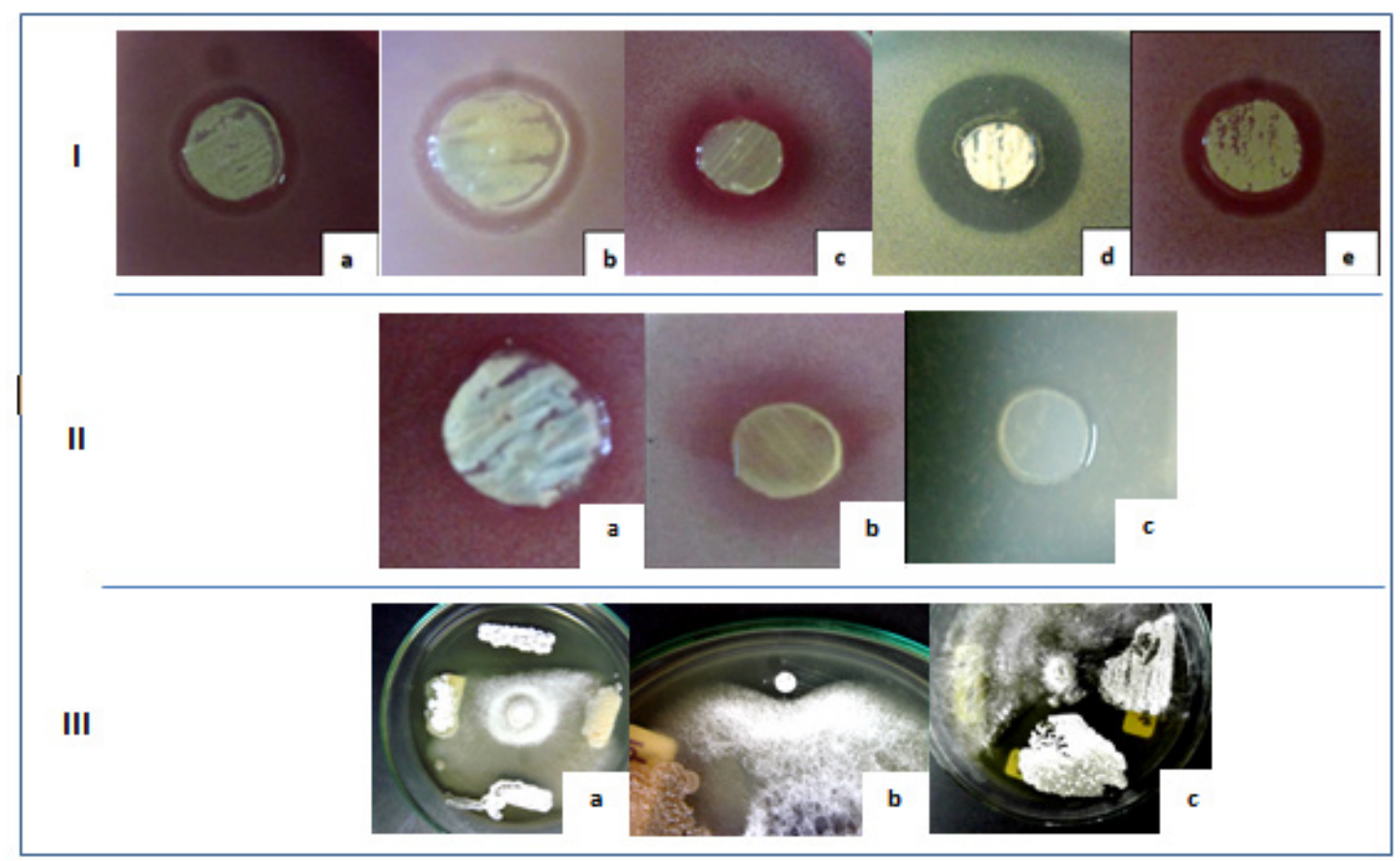

Figure 2. Inhibitory zone of antagonistic test to bacteria (incubated for $24 \mathrm{~h}$ at $37^{\circ} \mathrm{C}$ ) and fungi (incubated for seven days at $37^{\circ} \mathrm{C}$ ). (I) against Bacillus sp., are isolated CFR-6, CFR-18, CFR-19 CFR-17 and CFR-15, respectively. (II) against E. coli, a and b are isolated CFR-1 and CFR-15, while (c) is negative control media without bacteria added. (III) against the fungus F. oxsporum and Sclerotium sp, (a) CFR-29 and (b) CFR-12 isolates inhibit F. oxsporum, while (c) isolate CFR-35 inhibits Sclerotium sp.

pounds extracted from the scallop shells. Growth inhibition of the bacteria tested was predicted as the activity of bioactive compounds produced by actinomycetes isolates which will enter into bacteria through the cell wall, and then inhibit the process of protein, purines and nucleic acids synthesis that cause the damage to the proteins structure, denaturation of the cell wall, and eventually leading to the death of bacteria.

Besides having antibacterial and antifungal activity, previous studies showed that Streptomyces spp. has an ability to produce extracellular xylanase enzyme. Streptomyces olivaceoviridis A1 (Wang et al., 2007), Streptomyces thermonitrificans NTU-88 (Cheng et al., 2008), Streptomyces sp. S9 isolated from soil (Li et al., 2008), and Streptomyces sp. SWU10 isolated from rice straw (Deesukon et al., 2011), have been reported to produce xylanase enzymes that can be applied in various fields such as food, textiles, and waste handling. The test results of extracellular xylanase activity on xylan media suggested the formation of the widely clear zone; it indicated the activity on producing extracellular xylanase enzyme by actin- 
omycetes (Figure 3). From 34 isolates, six isolates have the ability to produce extracellular xylanase enzyme, they were isolated CFR-12, CFR-20, CFR-22, CFR-24, CFR-25, CFR-30, CFR-33 and CFR-34 (Table 2).

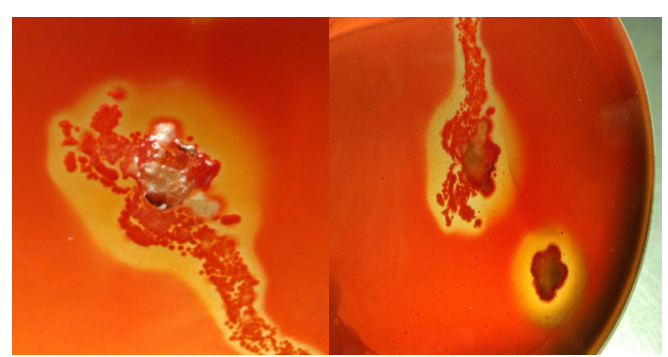

Figure 3. Clear zone produced by CFR-22 isolates after stained by congo-red.

Table 2. The diameter of clear zone produced by some actinomycetes isolates on xylan media before stained by congo-red.

\begin{tabular}{lccc}
\hline \multirow{2}{*}{$\begin{array}{c}\text { Number of } \\
\text { isolates }\end{array}$} & \multicolumn{3}{c}{ Diameter of clear zone } \\
\cline { 2 - 4 } & $\begin{array}{c}\text { Diameter } \\
\text { of isolate } \\
\left({ }^{\gamma}\right) \mathrm{mm}\end{array}$ & $\begin{array}{c}\text { Diameter of } \\
\text { clear zone } \\
\left({ }^{\gamma} \mathrm{O}\right) \mathrm{mm}\end{array}$ & $\begin{array}{c}\Delta^{\gamma}= \\
\gamma_{\mathrm{O}-}^{\gamma} \\
\mathrm{mm}\end{array}$ \\
\hline CFR-12 & 10.5 & 26.0 & 15.5 \\
CFR-20 & 11.5 & 20.75 & 9.25 \\
CFR-22 & 14.0 & 45.5 & 31.5 \\
CFR-24 & 9.75 & 24.75 & 15 \\
CFR-25 & 11.5 & 18.0 & 7.5 \\
CFR-30 & 12.75 & 41.5 & 29.25 \\
CFR-33 & 10.75 & 28.0 & 17.25 \\
CFR-34 & 10.25 & 28.5 & 18.25 \\
\hline
\end{tabular}

CFR-22 (Xyl_22) was the isolate that has an ability to produce extracellular xylanase enzyme with the widest clear zone (clear zone). The amplification of $16 \mathrm{~S}$ rRNA gene of isolate CFR22 (Xyl_22) using primers $63 \mathrm{~F}$ and $1387 \mathrm{R}$ with a size of 1300 bp DNA fragment was performed. The result of the sequence alignment isolate Xyl_22 using Blast.N program showed that this isolate has similar sequences with Streptomyces $\mathrm{sp}$, Streptomyces drozdowiczii, Streptomyces setonensis, Streptomyces sangleiri, Streptomyces atratus, and Streptomyces sporovirgulis with identity 99\% (Table 3) and E. value 0.0 within 2289 nucleotides.

Several studies showed that $S$. drozdowicii isolated from the soil has an important role in producing cellulose enzymes (Semedo et al., 2004). S. drozdowicii showed gray aerial mycelium with a smooth surface and colorless substrate mycelia. Type of spore chains are rectiflexible (RF). This statement supported the data from this study which is showed that isolate Xyl_22 has gray aerial mycelium, colorless substrate mycelia, and reflexible (RF) type of spore chain. But further research of that species as the xylanase enzyme producer has not been widely reported, so that the data in this study are believed to be the initial data that reported $S$. drozdowiciias extracellular xylanase producer.

Analysis of phylogenetic tree with bootstrap 1000x showed that isolate Xyl_22 was closely related to $S$. drozdowicii HBUM 175063 , with a value of $98 \%$ bootstrap. Based on phylogenetic tree analysis (Figure 4), it can be seen that isolate Xyl_22 belonged to the cluster of Streptomyces, and separated from Kocuria sediminis and Arthrobacter that belonged to actinomycetes group. In addition, isolate Xyl_22 was also separated from the out group species i.e. Gram-positive (Bacillus) and Gram-negative (Pseudomonas and Agrobacterium). It indicated that the isolate CFR 22 (Xyl_22) can be expressed as Streptomyces.

This research is the preliminary study to get information about potential actinomycetes isolated from protected forests CIFOR, Bogor. From this preliminary data, a clear picture about the actinomycetes isolates with their capabilities

Table 3. Percentage of $16 \mathrm{~S}$ rRNA gene sequence similarity of isolate Xyl_22

\begin{tabular}{|c|c|c|c|c|}
\hline Isolate & Species Affiliation (GenBank) & $\begin{array}{c}\text { Accession } \\
\text { number }\end{array}$ & $\begin{array}{c}E- \\
\text { value }\end{array}$ & $\begin{array}{l}\text { Similar- } \\
\text { ity }(\%)\end{array}$ \\
\hline \multirow{7}{*}{$\begin{array}{l}\text { Aktinomiset } \\
\text { CFR-22 } \\
\text { (Xyl_22) }\end{array}$} & $\begin{array}{l}\text { Streptomyces drozdowiczii } \\
\text { HBUM175063 }\end{array}$ & FJ486467.1 & 0.0 & 99 \\
\hline & Streptomyces sp. FZ12 & KF803308.1 & 0.0 & 99 \\
\hline & Streptomyces setonensis strain $17-1$ & EU367980.1 & 0.0 & 99 \\
\hline & $\begin{array}{l}\text { Streptomyces sangleiri strain NRBC } \\
100784\end{array}$ & NR041417.1 & 0.0 & 99 \\
\hline & Streptomyces sp. 80134 & AY996829.1 & 0.0 & 99 \\
\hline & Streptomyces atratus strain IHB B 8031 & KF475815.1 & 0.0 & 99 \\
\hline & Streptomyces sporovirgulis strain $\mathrm{UrC} 05$ & KF218589.1 & 0.0 & 99 \\
\hline
\end{tabular}




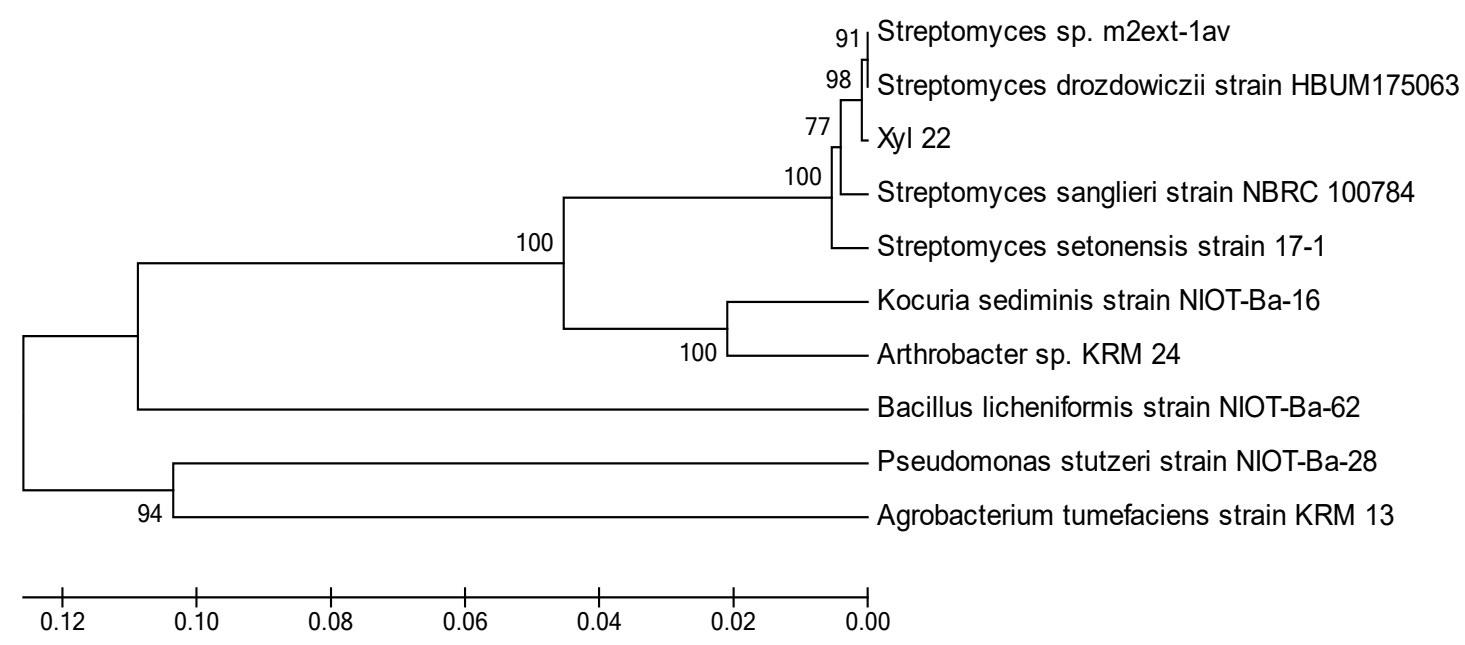

Figure 4. Phylogenetic tree of isolateCFR-22 (Xyl_22) based on 16S rRNA gene. The figure showed 16S rRNA sequence of isolate Xyl_22 closely related to the bacteria inside or outside the group. This phylogenetic tree was constructed using Neighbor Joining method with bootstrap 1000x replications.

to inhibit the growth of pathogenic bacteria such as Bacillus spp., E. coli was obtained. Several isolates were also reported to inhibit the growth of fungi that cause disease in agricultural products such as F. oxysporum and Sclerotium sp. However, the results of this study still need to be confirmed and tested further to get the specific active compounds which are capable of producing good antagonistic properties against the growth of bacteria and fungal pathogens. Overall, antibiosis compounds inhibit the pathogen through the inhibition of cell wall synthesis, cell membrane function, protein and nucleic acids synthesis (Brook et al., 2005).

Another interesting data showed that five isolates can potentially produce extracellular xylanase enzyme. Isolate CFR-22 (Xyl_22) has the highest xylanase activity. Nowadays, much attention has been paid to the study of xylanase-producing microbe; this is due to the wide application of this enzyme in various industries. Xylanase is used to improve the extraction of lignin and release the chromophore in the early stages of pulp bleaching. The use of xylanase in pulp and paper industry has been increased due to the discovery of microbes that capable of producing xylanase enzyme (Beg et al., 2001). Other applications include xylan conversion on agriculture and food industry, production of raw material for fuels and chemicals (Sunnah and Antranikian, 1997). This enzyme can also be used as bio-bleaching in the paper industry, purification, and enhancement of the grape juice aroma, and improvement the quality of bread and animal feed.

\section{CONCLUSION}

Based on the result, it can be concluded that 35 actinomycetes isolates have been successfully isolated from CIFOR forest soil which can be antibacterial, anti-fungal, and extracellular xylanase produce. The highest inhibitory activity against bacteria Bacillus spp. was showed by isolate CFR-07, while isolate CFR-15 showed the highest inhibitory activity against $E$. coli. The antagonistic test showed that isolate CFR-29 has potential ability to inhibit the growth of F. oxysporum while isolate CFR-35 showed inhibitory activity against the growth of Sclerotium sp.. Enzyme activity test of extracellular xylanase showed that isolate CFR-22 identified as $S$. drozdowicii has a potential role in producing extracellular xylanase enzyme that can be used in industrial applications.

\section{REFERENCES}

Aghighi, S. S., Bonjar, G.H., Rawashdeh, R., Batayneh, S., \& Saadoun, I. (2004) First report of antifungal spectra of activity of Iranian actinomycetes strains against Alternaria solani, Alternaria alternate, Fusarium solani, Phytophthora megasperma, Verticillium dahliae and Saccharomyces cerevisiae. Asian Jof Plant Sci, 3 (4), 463-471.

Ali, M. K., Rudolph, F.B. \& Bennett G.N. (2004). Thermostable xylanases 10B from Clostridium acetobotylicum ATCC824. J of Industrial Microbiol and Biotechol, 31, 229-234

Ambarwati, \& Trisnawati, G. A. (2009). Isolasi actinomycetes tanah sawah sebagai penghasil anti- 
biotik. Jurnal Penelitian Sains \& Teknologi,10(2), 101- 111.

Beg, Q. K., Kapoor, M., Mahajan, L., \& Hoondal, G.S. (2001). Microbial xylanase and their industrial application. Appl Microbiol Biotechnol, 56(3-4), 326-338.

Brook, F. G., Butel J. S., \& Morse S. A. 2005. Mikrobiologi kedokteran edisi 22. Jakarta: Salemba Medika Indonesia

Cheng, H. L., Wang, P. I., \& Chen, Y. C. (2008). Cloning, characterization and phylogenetic relationships of stxI, and endoxylanase-encoding gen from Streptomyces thermonitrificans NTU-88. Biores Technol, 99(1), 227-231.

Cao, L., Qiu, Z., You, J., Tan, H.,\& Zhou, S. (2005). Isolation and characterization of endophytic Streptomyces antagonists of Fusarium wilt pathogen from surface sterilized banana roots. FEMS Microbiol Lett, 247(2), 147-152.

Deesukon, W., Yuichi N., Naoki H., Tatsuji, S., \& Wasana, S. (2011). Purification, characterization and gene cloning of two forms of a thermostable endoxylanase from Streptomyces sp. SWU10. Proc Biochem, 46(12), 2255-2262.

Deobald, L. A., Crawford, D. (2002). Lignocellulose biodegradation. Didalam: Hurst, C. J., Crawford, R.L., Kudsen, G. R., Mclnerney, M. J.,Stetzenbach, L. D., (ed). Manual of enviromental microbiology. Edke-2. Washington: ASM Pr

Devillard, E., Christel, B. M., Harry, J. F., Karen, P. S., James, N., John, W., Jean-Pierre, J., \& Evelyne, F. (2003). Characterization of XYN10B, a modular xylanase from the ruminal protozoan polyplastron multivesiculatum, with a family 22 carbohydrate-binding module that binds tocellulose. Biochem J, 373(2), 495-503.

El-Tarabily, K. A., Soliman, M. H., Nassar, A.H., \& Al-Hassani, H. A.(2000). Biological control of Sclerotinia minor using a chitinolytic bacterium and actinomycetes. Plant Pathol, 49(5), 573-583.

Felsenstein, J. (1985). Confidence limits on phylogenies: an approach using the bootsrap. Evolution, 39, 783-791.

Ghadin, N., Noraziah, M. Z., Vikineswary, S., Norhidayah, B., Dayang, F. B., Hing, H.L \& Nik, M. S. (2008). Isolation and characterization of novel endophytic Streptomyces SUK 06 with antimicrobial activity from Malaysian plant. Asian J Plant Sci, 7(2), 189-194.

Gilbert, H. J., Hazlewood G. P. (1993). Bacterial cellulases and xylanases. J General Microbiol. 139(2), 187-194.

Georis, J., Giannotta, F., De Buylb, E, Granier B, \& Frere J. M. (2000). Purification and properties of three endo- $\alpha-1,4$-xylanases produced by Streptomyces sp. strain S38 which differ in their ability to enhance the bleaching of kraft pulps. Enzyme and Microbiol Technol, 26(2), 178-186.

Kaneko, S., Yuval, S., \& Yitzkak, H. (2000). Purification and characterization of a family G/11 $\alpha$-xylanase from Streptomyces olivaceoviridis
E-86. Bioschi Biotechl Biochem, 64(2), 447-451.

Kansoh, A. L.,\& Nagieb, Z. A. (2004). Xylanase and mannanase enzymes from Streptomyces galbus NR and their use in bioleaching of shoft wood kraft pulp. Antonie Van Leeuwenhoek, 85(2),103114

Li Ning., Kun, M., Yaru, W., Pengjun, S., Huiying, L., Yingguo, B., Peilong, Y.,\& Bin, Yao. (2008). Cloning, expression, and characterization of a news xylanase with broad temperature adaptability from Streptomyces sp. S9. Appl Microbiol Biotechnol, 80(2), 231-240.

Lin, J., Ndlovu, L. M., Singh, S., \& Pillay, B. (1999). Purification and biochemical characteristics of $\alpha$-D-xylanase from thermophilic fungus, Thermomyces lanuginosus-SSBP. Biotech Appl Biochem, 30(1), 73-79.

Madigan, M. T., Martinko, J. M., \& Parker,J. (2000). Brock: biology of microorganism. New Jersey American: Prentice Hall.

Marchesi, J. R.,Takuichi, S., Andrew, J. W., Tracey, A. M., John, C. F., Sarah, J. H., \& William, G. W. (1998). Design and evaluation of useful bacterium-spesific PCR primers that amplify genes coding for bacterial 16S rRNA. Appl Environ Microbiol, 64(2), 795-799.

Oskay, M. (2009). Antifungal and antibacterial compounds from Streptomyces strains. African $J$ of Biotechnol, 8(13), 135-142.

Perez, J., Munoz, D. J., Rubia T. D. L., \& Martinez J. (2002). Biodegradation and biological treatment of cellulose, hemicellulose and lignin: an overview. Int Microbiol, 5(2), 53-63.

Rochmawati, I., Muslimin, I., \& Reni, A. 2015. Aktivitas antibakteri ekstrak kerang pisau (Solen sp.) dan kerang simping (Placuna placenta). Biosaintifika: Journal of Biology \& Biology Education, 7(2), 128-135.

Ruiz-Arribas, A., Abalos, J. M. F., Shanchez, P., Garda, A. L., \& Santamaria, R. I. (1995). Over production, purification, and biochemical characterizationof a xylanases (xys1) from Streptomyces halstedii JM8. Appl Environ Microbiol, 61(6), 2414-2419.

Ryan, R. E.,De Buylb,V. \& E, Granier B. (2003). Purification and characterization of a new low molecular weight endoxylanase from Penicillium capsulatum. Enzym and Microbiol Technol, 33(6), 775-78.

Saha, B. C. (2003). Hemicellulose bioconversion. J Microbiol Biotechnol, 30(5), 279-291.

Semedo, L. T., Gomes, R. C., Linhares, A. A., Duarte, G. F., Nascimento, R. P., Rosado, A. S., Margis, P. M., Margis, R., Silva, K. R.,Alviano, C. S., Manfio, G. P., Soares, R. M., Linhares, L. F., \& Coelho, R. R. (2004). Streptomyces drozdowiczii sp. nov., a novel cellulolytic Streptomycetes from soil in Brazil. Int J Syst Evol Microbiol, 54(4), 1323-1328.

Shirling, E. B., \& Gottlieb, D. (1996). Methods for characterization of Streptomycetes species. Int $J$ Syst Bacteriol, 16(3), 313-340. 
Silveira, F. O. P., Ximenes, F. A., Cacais, A.O., Milagres, A.M., Meduros, C.V., Puls, J. \& Filho, E. X. (1999). Hydrolysis of xylans by enzyme systems from solid cultures of Trichoderma harzianum strains. Braz $J$ of Medial and Biol Res, 32(8), 947-952.

Subraminayan, S., \& Prema, S. (2002). Biotechnology of microbial xylanases: enzymology, molecular biology and aplication. Critical Rev Biotechnol, 22(1), 33-64.

Sunna, A., \& Antranikian, G. (1997). Characterization of the xilanase from the new isolated thermophilic xylan-degrading Bacillus thermoleovarans galur K-3d and Bacillus flavothermus galur LB3A. FEMS Microbial Lett, 148, 209-216.

Taechowisan, T., Lu, C., Shen, Y., Lumyong, S. (2005). Secondary metabolites from endophytic Streptomyces aureofaciens CMUAc 130 and their an- tifungal activity. Microbiol, 151(5), 1691-1695.

Tamura, K., Peterson, D., Peterson, N., Stecher, G., Nei, M., \& Kumar, S. (2011). MEGA5: molecular evolutionary genetics analysis using maximum likehood, evolutionary distance, and maximum parsimony methods. Mol Biol Evol, 28(10), 2731-2739.

Tseng, M. .J., Yap, M.N., Ratanakhanokchai, K., Kyu, K.L., \& Chen, S.T. (2002). Purification and partial characterization of two cellulase free xylanases from an alkaliphilic Bacillus firmus. Enzyme and Microbiol Technol, 30(5), 590-595.

Wang, Y., Zhang, H., He, Y., Luo, H., \& Yao, B. (2007). Characterization, gene cloning, and expression of a novel xylanase XYNB from Streptomyces olivaceoviridis A1. Aquaculture, 267(1), 328-334. 